\title{
TEOLOGIA
}

http://dx.doi.org/10.15633/sts.3536

KS. MAREK GILSKI

Studia Sandomierskie

WT UPJP2, Kraków

$26(2019)$

\section{ARGUMENTACJA SOBORU NICEJSKIEGO II ZA KULTEM IKON}

O ikonach i ich kulcie napisano już wiele. Ostatnia dekada przyniosła jednak dodatkowy impuls do badania tych zagadnień, ponieważ pojawiło się krytyczne wydane akt Soboru Nicejskiego II. Składa się ono z trzech tomów i obejmuje w sumie ponad tysiąc stron tekstu ${ }^{1}$. Połowa jest zredagowana w języku greckim, a druga część stanowi tłumaczenie łacińskie, przy czym nie zawsze jest to tylko tłumaczenie z greki. W niektórych wypadkach tekst łaciński zawiera te partie tekstu, które bądź to nie zachowały się po grecku, bądź też zostały na grekę przetłumaczone w sposób tendencyjny ${ }^{2}$.

Sobór Nicejski II (787) to najważniejszy w historii głos Kościoła na temat ikon $\mathrm{i}$ ich kultu. Chociaż nie był to jedyny punkt obrad, to jednak zajął on najwięcej miejsca w debatach. W czasie dyskusji wspomniano również na temat czci Biblii, krzyża czy relikwii, ale argumentacja za tworzeniem obrazów i oddawaniem im czci została przedstawiona w sposób najbardziej systematyczny. Było to związane z faktem, że przez ponad pięćdziesiąt lat (726-780) władcy Bizancjum zwalczali kult ikon. Stąd też ojcowie soborowi postanowili dać precyzyjną wykładnię na temat prawomocności tworzenia obrazów oraz ich roli i miejsca w Kościele.

1 Concilium Universale Nicaenum Secundum. Concilii actiones I - III, edidit E. Lamberz, W. de Gruyter, Berolini - Novi Eboraci MMVIII; Concilium Universale Nicaenum Secundum. Concilii actiones IV - V, edidit E. Lamberz, W. de Gruyter, Berlin-Boston 2012; Concilium Universale Nicaenum Secundum. Concilii actiones VI-VII, [dalej: CUNS] edidit E. Lamberz, W. de Gruyter, Berlin-Boston 2016. Tomy posiadają paginację ciągłą. Przebieg pierwszych trzech sesji znajduje się w tomie pierwszym na stronach: 18-281, czwartej i piątej w tomie drugim na stronach: 282-599, szóstej i siódmej w tomie trzecim na stronach: 600-857.

2 Chodzi na przykład o napisany po łacinie list papieża Hadriana do władców, który został na Soborze Nicejskim II odczytany w tłumaczeniu greckim. Odczytano go jednak w wersji niekompletnej i częściowo zmodyfikowanej. Fragmenty nawiązujące do Piotra apostoła podretuszowano w taki sposób, aby osłabić wydźwięk papieskiego prymatu. Por. CUNS, s. $118-171$. 
Sobór rozpoczął się od przyjęcia z powrotem do Kościoła nawróconych ikonoklastów i odczytania listów imperatorów (Ireny, Konstantyna VI), papieża Hadriana, patriarchy Tarazjusza oraz innych patriarchów (sesje I-III); następnie zaprezentowano pozytywny, oparty o Pismo Święte i Tradycję Kościoła, wykład na temat obrazów i możliwości ich kultu (sesje IV-V); kolejnym punktem obrad było zbijanie punkt po punkcie argumentów przeciwników kultu ikon (sesja VI); ostatnim akordem soboru było przyjęcie definicji dogmatycznej, po odczytaniu której miały miejsce zarówno krótkie aklamacje uczestników obrad, jak i rzucenie anatem na przeciwników kultu ikon (sesja VII).

Celem artykułu jest wydobycie z akt Soboru Nicejskiego II zawartych w nich argumentów przemawiających za kultem ikon ${ }^{3}$. Tak postawiony cel pozwoli znacząco poszerzyć przedstawianą w publikacjach naukowych argumentację za ich kultem. Okazuje się bowiem, że ojcowie soborowi przywołali o wiele więcej argumentów niż te najczęściej powtarzane w artykułach teologicznych bądź historycznych. W literaturze do najbardziej znanych argumentów za kultem ikon należą bowiem: argument z Pisma Świętego (teksty poświęcone cherubom, znajdującym się przy Arce Przymierza, które podważają absolutny charakter zakazu czynienia jakichkolwiek przedstawień), argument chrystologiczny (Niewidzialny, a zatem niemożliwy do przedstawienia obrazowego Bóg, stał się widzialny, czyli podatny na przedstawienie dzięki Wcieleniu; Jezus Chrystus jest obrazem Boga niewidzialnego, a zatem Bóg sam sobie uczynił obraz), argument z Tradycji (liczni ojcowie Kościoła sami czcili ikony i zachęcali innych do ich kultu) i argument z cudów (uzdrowienia za pośrednictwem ikon) ${ }^{4}$. Rzadziej przytaczane są ponadto argumenty: ex pacifica possessione oraz z analogii ${ }^{5}$. Pierwszy podkreśla, że przez wieki ikony były czczone i nikt tego nie podważał (jest więc $\mathrm{w}$ gruncie rzeczy elementem argumentu $\mathrm{z}$ Tradycji), drugi natomiast nawiązuje do samej teorii obrazu, który jest odpowiednikiem słowa, zapisanego w inny sposób (zamiast literami to kolorami).

Obecne przedłożenie będzie próbą przedstawienia wszystkich przywołanych w debatach soborowych argumentów. Jest ich jedenaście. Chodzi o następujące argumenty za tworzeniem ikon i ich kultem: z Biblii, z wcielenia, z Tradycji, z powszechności, z cudów, z intencji, z owoców duchowych, z analogii, z teorii obrazu, $\mathrm{z}$ istnienia obrazów nie ręką ludzką uczynionych. Ostatni argument ma charakter logicznej reductio ad absurdum.

3 W artykule terminy „obraz” i ,ikona” stosowane są jako synonimiczne. Jak wiadomo, oba pojęcia mają odmienne konotacje. Celem artykułu jest jednak przedstawienie argumentacji za możliwością tworzenia i oddawania czci jakimkolwiek przedstawieniom Boga, Maryi i świętych. To wydaje się upoważniać do takiego synonimicznego traktowania obu terminów.

4 B. Tschiflianow, The Iconoclastic Controversy - A Theological Perspective, „, The Greek Ortodox Theological Review" 38 (1993), s. 231-264.

5 T. D. Łukaszuk, Obraz święty - ikona wżyciu, w wierze i w teologii Kościoła, Częstochowa 1993, s. 73-88. 
Na czym polega novum tego artykułu? Po pierwsze, na syntetycznym przedstawieniu argumentacji za kultem ikon, zawartej na kartach akt Soboru Nicejskiego II. Brak jest artykułu, który właśnie w oparciu o same akta referowałby tę kwestię. Po drugie, w licznych pozycjach podejmujących tematykę ikon przytacza się niekompletną argumentację za ich kultem. To prawda, że większość argumentów była przedmiotem zainteresowania badaczy. Te teksty są cytowane w publikacjach historycznych, teologicznych, a nawet z obszaru historii sztuki. Sama analiza akt Soboru Nicejskiego II zajmuje jednak niewiele miejsca w publikacjach naukowych. Chociaż Hans Georg Thümmel ${ }^{6}$ referuje zagadnienia omawiane na poszczególnych sesjach niemal na 50 stronach (s. 133-180), to jednak aspekty teologiczne są przez niego potraktowane bardzo zdawkowo. Sesja VI, polemiczna wobec synodu z Hieria, jest omawiana na jednej stronie. Monografia Daniela Sahasa pt. Icon and Logos. Sources in Eight-Century Iconoclasm ${ }^{7}$ zawiera krótkie omówienie argumentacji za kultem ikon, koncentrujące się przede wszystkim na konsekwencjach wcielenia. Autor opatruje krótkim komentarzem swój przekład na język angielski VI sesji Soboru Nicejskiego II. Inni autorzy (L. Brubaker, L. Brubaker i J. Haldon ${ }^{9}$ ) przyjmują bardziej perspektywę historyczną aniżeli teologiczną. Prezentują szerokie tło sporów ikonoklastycznych, zdawkowo traktując dorobek samego Soboru Nicejskiego II. Chociaż L. Uspienski ${ }^{10}$, T. D. Łukaszuk ${ }^{11}$, Ch. Schőnborn ${ }^{12}$ koncentrują się na zagadnieniach teologicznych, to jednak ich analizy są niekompletne. Za najważniejszy tekst należałoby w tym temacie uznać pozycję A. Giakalisa ${ }^{13}$, ponieważ ma ona sensu stricto charakter teologicznego omówienia dorobku teologicznego Soboru Nicejskiego II. Ale i tam argumentacja nie jest kompletna. Brak jest w dotychczasowej literaturze przedmiotu przedstawienia argumentu z intencji, omówienia swoistej reductio ad absurdum tez ikonoklastów, a przede wszystkim brak jest pogłębienia argumentu z Tradycji, to znaczy faktycznego, a nie tylko hasłowego, zmierzenia się z powoływaniem się na Tradycję przez ikonoklastów.

6 H.G. Thümell, Die Konzilien zur Bilderfrage im 8. Und 9. Jahrhundert. Das 7. Ökumenische Konzil in Nikaia 787, Padeborn-München-Wien-Zürich 2005.

7 D. J. Sahas, Icon and Logos. Sources in Eight-Century Iconoclasm, Toronto-BuffaloLondon 1986.

8 L. Brubaker, Inventing Byzantine Iconoclasm, London 2012.

9 L. Brubaker, J. Haldon, Byzantium in the Iconoclast Era, c. 680-850. A History, Cambridge 2015.

10 L. Uspienski, Teologia ikony, Poznań 1983.

11 T. D. Łukaszuk, Obraz święty..., dz. cyt.

12 Ch. Schőnborn, Ikona Chrystusa, Poznań 2001.

13 A. Giakalis, Images of the Divine. The Theology of Icons at the Seventh Ecumenical Council, Leiden 1994. 


\section{Argument z Pisma Świętego}

Czwarta sesja soboru rozpoczęła się od przedstawienia argumentacji na rzecz tworzenia ikon i ich kultu. Punktem wyjścia były dla ojców soborowych teksty Starego i Nowego Testamentu nawiązujące do Arki Przymierza. Przeczytano publicznie cztery fragmenty (Wj 25, 1.17-22; Lb 7,88-89; Ez 41,1.16-20; Hbr 9,1-5) ${ }^{14}$. W debacie nad nimi zwrócono uwagę, że jak kiedyś cheruby były przy Przebłagalni, osłaniając ją, tak samo i dziś ikony Jezusa i Maryi osłaniają ołtarz. Cheruby były dziełami sztuki i miały ludzką twarz ${ }^{15}$. Przytoczone biblijne fragmenty stanowiły dla ojców soborowych wystarczający dowód, że zawarty w Księdze Wyjścia $(20,4)$ zakaz czynienia jakichkolwiek przedstawień nie miał charakteru absolutnego, a zatem dopuszczał wyjątki, skoro sam Bóg nakazał wykonanie cherubów. W toku dyskusji odwołano się także do przykładu świętych, którzy mieli wizje aniołów ukazujących się im w ludzkiej postaci.

W dalszej debacie przytoczono te fragmenty biblijne, które nawiązywały do przedmiotów bądź to wykonanych dla Boga (stela Jakuba) ${ }^{16}$, bądź to będących przedmiotem czci (Jakub uczcił wierzchołek laski Józefa) ${ }^{17}$. Biblia nie określała tych wytworów ludzkich rąk ani tych form czci mianem bałwochwalstwa. Tym bardziej, że jak zauważono w toku obrad soborowych, w Starym Testamencie znajdują się przykłady czci okazywanej grzesznikom: Abraham oddał pokłon do ziemi Chetytom, którzy sprzedali mu grób, aby mógł pochować Sarę (Rdz 23,7); Jakub pobłogosławił faraona (Rdz 47,7) i oddał pokłon swemu bratu Ezawowi (Rdz 33,3), Mojżesz oddał pokłon Jetrze (Wj 18,7). Żaden z tych wyrazów czci nie był bałwochwalstwem, ponieważ nie chodziło o traktowanie tych osób jako bóstw ${ }^{18}$.

Wielokrotnie przywoływane w czasie obrad soborowych teksty biblijne pozwoliły ukazać biblijny zakaz czynienia obrazów w jego właściwym kontekście. Chociaż pełnił on ważną funkcję chroniącą naród wybrany przed bałwochwalstwem, to jednak nie miał on charakteru absolutnego.

\section{Argument $\mathrm{z}$ wcielenia}

Prawda o wcieleniu Syna Bożego wielokrotnie wybrzmiewa w aktach soborowych. Co prawda, ani raz zwolennicy kultu ikon nie przywołali tekstu z Listu do Kolosan $(1,15)$, wskazującego na Jezusa Chrystusa jako obraz Boga niewidzialnego. Było to spowodowane faktem, że do tego fragmentu nawiązywali ikonoklaści na

${ }^{14}$ CUNS, s. 284-288. Te same teksty były również cytowane nie tylko na wcześniejszych, ale i na późniejszych sesjach przy okazji lektury różnych pism. Por. CUNS, s. 130, 156, 366.

15 Ten argument kilkakrotnie pojawia się w dokumentach soborowych. Por. CUNS, s. 288, 350 .

16 Rdz 28,13-18; CUNS, s. 130.

17 Hbr 11,21; CUNS, s. 130, 356.

18 CUNS, s. 356, 368. Akta odwołują się jeszcze do przykładu Daniela, który oddał pokłon Nabuchodonozorowi. Według Dn 2,46 chodziło jednak o sytuację odwrotną. 
synodzie w Hieria ${ }^{19}$. Mimo to prawda o wcieleniu na różne sposoby wybrzmiewała w auli soborowej. Celem obrazów była obrona prawdy o rzeczywistym, a nie pozornym wcieleniu Syna Bożego. Dlatego też kilkakrotnie cytowano kanon 82. Soboru Piąto-Szóstego, który w trosce o wiarę we wcielenie Syna Bożego nakazywał przedstawiać Go nie jako Baranka, lecz w ludzkim kształcie. Podstawą możliwości czynienia ikon Jezusa Chrystusa jest fakt wcielenia. Nie chodzi bowiem o przedstawianie na obrazach boskiej natury Logosu, bo to jest niemożliwe. Skoro jednak był widziany w ludzkim kształcie, to w takiej postaci może również zostać namalowa$n y^{20}$. W tym kontekście przywoływano szereg biblijnych fragmentów, świadczących o tym, że Jezus był widziany zarówno przed, jak i po zmartwychwstaniu ${ }^{21}$.

Sesja VI soboru była jednak świadkiem pogłębionej dyskusji nad prawdą o wcieleniu, ponieważ nie tylko ikonodule, ale i ikonoklaści opierali swoją argumentację na niej. Ci pierwsi widzieli w nim argument za możliwością tworzenia ikon, ci drudzy natomiast postrzegali ikonę, jako sprzeczny z orzeczeniami wcześniejszych soborów, przykład mieszania natur lub przekonania o istnieniu w Jezusie Chrystusie dwóch hipostaz $^{22}$.

Wyjaśnienie prawdy o wcieleniu dokonało się przede wszystkim w oparciu o słowa i czyny samego Jezusa, które pozwalały widzieć we wcieleniu przykład przejścia od nieskończoności do skończoności. Dowodem miała być np. wypowiedź Jezusa w kontekście śmierci Łazarza, wyrażająca radość, że Go nie było przy zgonie przyjaciela (J 11,11.15). Te słowa są świadectwem na to, że Wszechobecny Bóg przyjął przez wcielenie ludzkie ograniczenia ${ }^{23}$. Jako argument przytoczono również problem malowania obrazów ludzi. Na takich przedstawieniach nie jest możliwe zaprezentowanie ludzkiej duszy, która jest niewidzialna ${ }^{24}$.

Związek ikony z chrystologią wydaje się być dwojaki. Argument chrystologiczny, prawda o Bogu, który stał się człowiekiem, stanowił dla ojców soborowych uzasadnienie dla możliwości czynienia obrazów Jezusa Chrystusa. Z drugiej jednak strony ikona pełniła funkcję apologetyczną, uzasadniającą prawdziwość i realność wcielenia.

\section{Argument z Tradycji}

Termin „Tradycja” to jedno z najczęściej przywoływanych na soborze słów. Sobór przeszedł do historii jako ten, który dał jedno z najdobitniejszych stwierdzeń

19 Odwołanie do Biblii pojawia się jako cytat z synodu w Hieria. Por. CUNS, s. 656. Ojcowie soborowi przywoływali natomiast fragment z Listu do Hebrajczyków $(1,3)$ o Synu Bożym jako odblasku i odbiciu hipostazy Ojca. Por. CUNS, s. 760, 870.

20 CUNS, s. 446, 542, 578.

${ }^{21}$ CUNS, s. 742, 762.

${ }^{22}$ CUNS, s. 760-768.

${ }^{23}$ CUNS, s. 762. Przywołano także przykłady ukazywania się Jezusa po zmartwychwstaniu wraz z możliwością dotykania Go przez Tomasza.

24 CUNS, s. 764. 
magisterium Kościoła na temat Tradycji ${ }^{25}$. Argumentacja z Tradycji szła na soborze zasadniczo trzema torami: po pierwsze, były to stwierdzenia o charakterze ogólnym podkreślające, że kult obrazów Jezusa Chrystusa, Maryi, apostołów i świętych jest obecny w Kościele od początku, a więc nie jest to Tradycja nowa, lecz przekazana przez ojców ${ }^{26}$; po drugie, kilkakrotnie w czasie obrad soborowych cytowano postanowienia wcześniejszych orzeczeń Kościoła, a przede wszystkim tzw. Soboru Piąto-Szóstego, który w kanonie 82. zakazywał przedstawiania Jezusa Chrystusa jako Baranka, polecając malowanie Go na obrazach w ludzkim kształcie, aby patrzący, rozmyślając o ogromie poniżenia Bożego Słowa, przypominali sobie Jego życie w ciele, mękę, śmierć i odkupienie ${ }^{27}$; po trzecie, przytaczano wzmianki z pism pisarzy wczesnochrześcijańskich o czci należnej obrazom. Do najczęściej przywoływanych ojców broniących kultu ikon należał Bazyli Wielki ${ }^{28}$.

Argument z Tradycji napotkał na soborze na niespodziewaną przeszkodę, ponieważ także przeciwnicy tworzenia obrazów i ich kultu powoływali się na ojców Kościoła, cytując przede wszystkim pisma Epifaniusza z Salaminy ${ }^{29}$. Autorytet żyjącego w IV w. cypryjskiego biskupa był tak duży, że trzeba było wnikliwie przemyśleć tę kwestię i dlatego sporo miejsca poświęcono argumentowi z Tradycji jako takiemu. Kluczowym argumentem za tym, że opinia jednego z ojców Kościoła nie oznacza jeszcze pojawienia się Tradycji w Kościele, było odwołanie się do kategorii kontynuacji i recepcji. Uczniowie św. Epifaniusza, nie tylko bowiem nie podzielali jego poglądów, lecz nawet zbudowali kościół pod jego wezwaniem i umieścili w nim ikony swojego mistrza ${ }^{30}$. Tak więc, w przekonaniu ojców soborowych, nie należy traktować jako Tradycji w Kościele odosobnionej opinii nawet największych autorytetów. Skoro uczniowie Epifaniusza z Salaminy nie byli kontynuatorami jego sposobu myślenia, a zatem nie doszło do recepcji jego poglądów, to znaczy, że nie wytworzyła się w Kościele Tradycja przeciwna kultowi obrazów.

Ikonoklaści powoływali się również na innych wczesnochrześcijańskich pisarzy, cytując ich teksty krytyczne wobec tworzenia ikon i ich kultu. Ojcowie soborowi w niektórych przypadkach podważyli autentyzm przytaczanych fragmentów

${ }^{25}$ Y. Congar, Tradycja i tradycje, Poznań-Warszawa 2018, s. 84. W końcowej definicji wiary sobór zdefiniował Tradycję jako „nauczanie naszych świętych ojców”, dodając, że jest ona napełniona Bogiem i mieszka w niej Duch Święty. Analiza tych sformułowań znajduje się w: M. Gilski, M. Cholewa, Język soborów pierwszego tysiąclecia, Kraków 2018, s. 128-129.

${ }^{26}$ CUNS, s. 127. Wielokrotnie w aktach soborowych pojawia się krytyka wszelkiego rodzaju nowinkarstwa. Por. CUNS, s. 40, 48, 192, 260-262.

27 CUNS, s. 176-178, 240, 344-346, 620-622.

${ }_{28}$ CUNS, s. 58, 68, 72, 138, 140, 400.

29 Przyczyny negatywnej postawy Epifaniusza wobec obrazów referuje: O. Solovieva, Epiphanius of Salamis and His Invention of Iconoclasm in the Fourth Century A.D., „Fides et Historia” 42 (2010), z. 1, s. 21-46.

30 CUNS, s. 710-712. 
(np. dzieła Teodota z Ancyry, niektóre teksty Epifaniusza z Salaminy) ${ }^{31}$, a w innych (np. teksty Euzebiusza z Cezarei) ${ }^{32}$ zakwalifikowali ich autorów jako zwolenników herezji, a w jeszcze innych zakwestionowali interpretację jako wypaczającą ich rzeczywisty sens (np. cytaty z dzieł Grzegorza Teologa, Jana Chryzostoma, Atanazego Wielkiego $)^{33}$.

Udało się zatem na soborze nie tylko pokazać istnienie pochodzącej już od czasów apostolskich tradycji czynienia obrazów, lecz także dopracować rozumienie Tradycji w Kościele, podważając próby udowodnienia istnienia tradycji przeciwnej czci obrazów.

\section{Argument z powszechności}

Argument z powszechności był na soborze przywoływany w dwóch kontekstach. Chodziło zarówno o cały świat chrześcijański, jak i o inne religie. Ojcowie soborowi zwrócili uwagę, że wszędzie tam, gdzie są chrześcijanie, są czczone ikony ${ }^{34}$. Inne religie natomiast, chociaż nie czczą ikon, to jednak czczą nie tylko Boga, ale i pewne przedmioty. Żydzi otaczają czcią tablice z przykazaniami ${ }^{35}$, Arkę, ołtarz, cheruby, Przebłagalnię, dzban z manną, Księgę Prawa, z szacunkiem i czcią potraktowali także kości Józefa, zabierając je z Egiptu (Wj 13,19) ${ }^{36}$.

Te przykłady posłużyły ojcom soborowym jako argument za kultem nie tylko ikon, ale i krzyża oraz relikwii. Argument z powszechności nie został na soborze szerzej rozwinięty.

\section{Argument taumaturgiczny}

Argument taumaturgiczny wydaje się zajmować najwięcej miejsca w soborowej debacie. Przywołano wiele cudów, a opisy niektórych były nawet kilkakrotnie odczytywane, ponieważ znajdowały się w różnych dziełach.

W ramach cudów dokonanych za pośrednictwem ikon przytoczono przede wszystkim przykłady uzdrowień z chorób (trąd, bezpłodność, wrzody, ból, liczne bliżej nie sprecyzowane uleczenia), wypędzeń złych duchów, nawróceń (prostytutka, mieszkańcy Bejrutu), ocaleń z niewoli barbarzyńców, a nawet otrzymania zdolności opanowania na pamięć całego Psałterza. Przywołano również przykłady cudów karzących, związanych z próbami bądź to znieważania ikon, bądź to ich zniszczenia ${ }^{37}$.

31 CUNS, s, 708, 728-730.

32 CUNS, s. 732-736.

${ }^{33}$ CUNS, s. 712-716.

34 CUNS, s. 128.

35 CUNS, s. 160. Jako dowód powołano się na św. Hieronima.

36 CUNS, s. 354, 364-366. Przy tej okazji wspomniano również o Namiocie Spotkania, efodzie, różdżce Mojżesza, skale z Meriba, z której wypłynęła woda, oraz krzewie gorejącym.

37 Ponad połowa czwartej sesji była poświęcona odczytywaniu dzieł, które zawierały opis cudów dokonanych za pośrednictwem ikon. Por. CUNS, s. 316-334, 376-380, 386-392, 
Przy tej okazji odwołano się również do opisanej w Księdze Liczb $(21,8-9)$ historii o wężu miedzianym. Skoro wystarczyło na niego spojrzeć i to powodowało uzdrowienie, to o ileż bardziej przyniesie uleczenie z wszelkiej choroby spojrzenie na obraz Chrystusa czy świętych ${ }^{38}$.

Logika argumentacji była jasna. Za pośrednictwem ikon Bóg dokonuje cudów, a zatem ich tworzenie i oddawanie im czci jest legitymizowane przez Niego samego. Przywołane w auli soborowej opisy cudów dokonywały się za pośrednictwem zarówno ikon Jezusa Chrystusa, jak i ikon Bożej Rodzicieli oraz świętych.

\section{Argument $\mathrm{z}$ intencji}

Kilkakrotnie w auli soborowej podkreślano znaczenie intencji, z jaką tworzone są obrazy. Wszelkie dzieło bowiem - jak stwierdził Stefan, biskup Bosry, mając na myśli ikony świętych - które zostało uczynione w imię Boże, jest dobre i święte ${ }^{39}$. Ten sam pogląd, choć w nieco innych słowach powracał jeszcze w czasie soborowych dyskusji, w nawiązaniu do Listu do Kolosan $(3,17)^{40}$, w którym święty Paweł zachęca, aby czynić wszystko w imię Pańskie. To, co zostało poświęcone Bogu podkreślili ojcowie soborowi - nie może być wynalazkiem diabła ${ }^{41}$.

Nie udało się znaleźć w aktach soborowych żadnych wzmianek na temat obrazów demonów, jakkolwiek wspominano o obrazach władców. Debaty dotyczyły jednak jedynie prawomocności tworzenia obrazów, które przedstawiały Jezusa Chrystusa, Maryję, aniołów lub świętych. Dlatego też argument tworzenia ikon w imię Boże nie wymagał dodatkowych uzasadnień.

\section{Argument z owoców duchowych}

Istotnym argumentem za tworzeniem ikon, była także zdolność do wewnętrznej przemiany osób na nie patrzących. Niektóre ikony prowadziły do skruchy, do płaczu, a nawet wyzwalały pragnienie świętości. Te łzy, rodzące się na widok obrazu, a nie pod wpływem słów, stanowiły dla ojców soborowych ważny argument za tworzeniem ikon. Przywołano przykład Grzegorza z Nyssy, który nie mógł powstrzymać łez na widok obrazu przedstawiającego Abrahama składającego w ofierze Izaaka ${ }^{42}$. Ikony świętych - jak to niejednokrotnie podkreślano - nie są tworzone po to, aby je czcić jak bogów, ale po to, żeby patrzących na nie pobudzić do współzawodnictwa ${ }^{43}$.

404-434, 476-478. W czasie drugiej sesji odwołano się do legendy o uzdrowieniu cesarza Konstantyna z trądu. Por. CUNS, s. 122-124.

38 CUNS, s. 132.

39 CUNS, s. 152-154.

40 CUNS, s. 440.

${ }^{41}$ CUNS, s. 754.

42 CUNS, s. 294. Por. CUNS, s. 136.

${ }^{43}$ CUNS, s. 578, 772. 
Kilkakrotnie w soborowych aktach pojawia się termin mimesis ${ }^{44}$ oznaczający naśladowanie ${ }^{45}$. Jedną $\mathrm{z}$ funkcji ikon jest bowiem wezwanie do naśladowania. To, co widzialne, ma bowiem porywać do kontemplowania tego, co niewidzialne, a następnie do działania ${ }^{46}$. Dowodem na takie działanie obrazów były nawrócenia spowodowane za ich pośrednictwem ${ }^{47}$. Soborowa doktryna na temat obrazów łączy w sobie dwie ważne kategorie: naśladowanie i współzawodnictwo. Ikony miały prowadzić najpierw do naśladowania przedstawionych na obrazach postaci świętych, a następnie do prób współzawodnictwa z nimi, aby osiągnąć większy niż oni stopień świętości.

W czasie szóstej sesji soboru pojawił się również temat owoców, które zrodziła postawa zwalczania ikon i ich kultu. Przywołano przykłady wywołanych przez ikonoklastów prześladowań, w czasie których miały miejsce: pozbawianie wolności, biczowania, oślepiania, obcinania nosów i języków, grabieże, przymusowe małżeństwa dziewic, profanacje świątyń, niszczenie naczyń liturgicznych, zamiany klasztorów w gospody, palenie ksiąg, morderstwa oraz wiele innych form represji wobec czcicieli obrazów ${ }^{48}$.

\section{Argument $\mathrm{z}$ analogii}

W debatach soborowych odwołano się także do relacji między słowem a obrazem. W obu przypadkach mamy, w przekonaniu ojców soborowych, do czynienia z jakąś formą zapisu: bądź to przy pomocy liter, bądź to przy pomocy kolorów. Słowa są zapisywane w księgach, a kolory na drewnie ${ }^{49}$. Powołując się na takie autorytety jak Bazyli Wielki czy Atanazy Wielki, uznano prawomocność obu tych form przekazu ewangelicznego ${ }^{50}$. Odwołując się zaś do tekstów papieża Grzegorza Wielkiego, wspomniano o obrazach jako Biblia pauperum ${ }^{51}$.

\section{Argument z teorii obrazu}

Papież Hadrian w swoim liście do imperatorów, odczytanym na II sesji soboru, zdefiniował ikonę Boga jako oblicze (prosopon) Boga ${ }^{52}$. Wielokrotnie na soborze podejmowano próbę opisania relacji między obrazem a przedstawioną na nim osobą. Podkreślano przy tej okazji następujące kwestie: po pierwsze, cześć dla obrazu nie jest czcią dla drewna lub kolorów, ale dla prototypu, czyli osoby, która na nim jest

${ }^{44}$ Nie zawsze w formie rzeczownika mimesis, lecz częściej w formie czasownika mimeomai.

${ }^{45}$ CUNS, s. 136, 140, 158, 306. Por. G. W. H. Lampe, A Patristic Greek Lexikon, Oxford 1961, s. 871-872.

${ }^{46}$ CUNS, s. 128.

${ }^{47}$ CUNS, s. 302.

${ }^{48}$ CUNS, s. 752.

${ }^{49}$ O wartości zmysłów ludzkich w drodze ku Bogu: CUNS, s. 786.

${ }^{50}$ CUNS, s. 140, 148.

${ }_{51}$ CUNS, s. 126.

${ }^{52}$ CUNS, s. 134. 
namalowana ${ }^{53}$; po drugie, obraz nie jest samodzielnym bytem, co oznacza, że jeśli np. władca ma obraz, to nie oznacza to istnienia dwóch władców ${ }^{54}$; po trzecie, obraz i osobę na nim przedstawioną łączy nazwa, a nie istota (ousia) ${ }^{55}$.

Każda z tych tez została w czasie soborowych debat opatrzona przykładem. Ścisły związek obrazu z osobą został ukazany przez odwołanie się do władzy świeckiej. Brak szacunku dla obrazu władcy, jest przecież jednoznacznie interpretowany jako brak szacunku dla samego władcy. I analogicznie cześć dla figury i obrazu władcy jest czcią okazywaną jemu samemu. Przy tej okazji przypomniano o różnego rodzaju zwyczajach obnoszenia obrazów ludzi panujących po miastach ${ }^{56}$. Z podobną sytuacją mamy do czynienia w przypadku Żydów czczących Księgę Prawa. Nie chodzi przecież o oddawanie czci skórze, na której jest spisana, lecz zawartemu w księdze Słowu Boga ${ }^{57}$. Z drugiej strony w odpowiedzi na zarzuty ikonoklastów o nestorianizm, odpowiadano, że obraz i osoba na nim przedstawiona nie są dwoma osoba$\mathrm{mi}^{58}$. Obrazy nie dzielą Chrystusa, ale przedstawiają Słowo, które stało się ciałem i zamieszkało między nami ${ }^{59}$. W polemice z ikonoklastami, utrzymującymi, że obraz musi być z tej samej materii co namalowana postać (takie kryterium spełniała jedynie Eucharystia $)^{60}$, ojcowie soborowi podkreślali, że choć istnieje związek między ikoną a osobą, to jednak łączy te dwie rzeczywistości jedynie nazwa. Nigdy bowiem Ciało i Krew Jezusa nie były przez ojców Kościoła nazywane obrazami. Stąd teoria ikony prezentowana przez ikonoklastów nie ma żadnego oparcia w Tradycji ${ }^{61}$.

\section{Argument $\mathrm{z}$ istnienia obrazów nie ręką ludzką uczynionych}

Dla potwierdzenia słuszności czynienia obrazów ojcowie soborowi odwołali się także do przykładu obrazów nie namalowanych przez ludzi. Zostały one określone bądź to jako „wykonane przez Boga”, bądź to jako „nie ręką ludzką uczynione"62. Chodziło przede wszystkim o obraz Jezusa Chrystusa przekazany, zgodnie z legendą, Abgarowi. W czasie V sesji soboru odczytano fragment czwartej księgi Historii Kościoła autorstwa Ewagriusza Scholastyka opisujący cud dokonany za pośrednictwem właśnie tego „całego świętego” i nie ręką ludzką uczynionego obrazu ${ }^{63}$. Dzięki

53 CUNS, s. 130, 144, 398. Z podobną sytuacją mamy do czynienia w przypadku krzyża. Por. CUNS, s. 352.

54 CUNS, s. 150.

55 CUNS, s. 664, 670, 682, 744.

56 CUNS, s. 142-144, 394.

57 CUNS, s. 354.

58 CUNS, s. 398.

59 Na temat zarzutu nestorianizmu i odpowiedzi soboru: CUNS, s. 648.

60 CUNS, s. 670-672.

${ }^{61}$ CUNS, s. 672-676.

${ }^{62}$ CUNS, s. 582.

${ }^{63}$ Ewagriusz Scholastyk, Historia Kościoła, IV, 27, thum. S. Kazikowski, Warszawa 1990, s. 197-199. 
przyniesieniu tego wizerunku Jezusa udało się w sposób cudowny ocalić oblężoną Edessę $^{64}$. Jeden z uczestników soboru dał osobiste świadectwo, że w czasie swojej wizyty w Syrii nie tylko widział ten święty obraz, ale i był świadkiem oddawanej mu czci ${ }^{65}$.

W auli soborowej przywołano również przykłady innych obrazów i napisów, które nie pochodziły od ludzi. Gdy pewien święty człowiek zamówił u rzemieślnika wykonanie krzyża, okazało się, że pojawiły się na krzyżu nie tylko napisy, ale i trzy obrazy. Napisy wskazywały, że chodziło o postacie Emmanuela, Gabriela i Michała. Rzemieślnik próbował je usunąć, ale nie był w stanie ${ }^{66}$.

W tę samą logikę wpisują się również odwołania do stworzenia Adama na obraz i podobieństwo Boga ${ }^{67}$. Chodzi o obraz nie ręką ludzką uczyniony.

Chociaż ojcowie soborowi nie omawiali szczegółowo kwestii ikon nie ręką ludzką uczynionych, a jedynie potwierdzali ich istnienie, to jednak tym samym wskazywali na boskie a nie ludzkie pochodzenie samej tradycji ich czynienia.

\section{Reductio ad absurdum}

Ojcowie soborowi w odpowiedzi na zarzut, że oddawanie czci ikonom świętych jest bałwochwalstwem, zastosowali logiczny wywód pozwalający sprowadzić myślenie ikonoklastów do absurdu. Jak bowiem - pytali uczestnicy soboru - może być bałwochwalstwem kult męczenników, którzy niszczyli wszelkie formy bałwochwalstwa? Jak może być przejawem bałwochwalstwa oddanie czci kościom, prochom, krwi tych, którzy nie tylko nie składali czci bożkom, ale i walczyli z wszelkimi formami bałwochwalstwa? Gdyby kult ikon był kultem bożków, to jak byłoby możliwe, żeby za pośrednictwem ikon dochodziło do wyrzucania złych duchów?68. Te i inne głosy, padające w auli soborowej, miały charakter swoistego reductio ad absurdum. Ukazywały absurd myślenia ikonoklastów. W celu jeszcze dobitniejszego ukazania braku racjonalności w myśleniu ikonoklastów, przywołano historię pustelnika z Góry Oliwnej czczącego ikonę Maryi z Dzieciątkiem, nieustannie nękanego z tego powodu przez złego ducha. W pewnym momencie demon mu się ukazał, zachęcając go do zaniechania modlitwy przed obrazem, proponując, że w zamian zaprzestanie kuszenia go $^{69}$. Każda ikona świętego jest w przekonaniu ojców soborowych, znakiem nie tylko jego walki przeciw diabłu, ale i odniesionego w tej konfronta-

${ }^{64}$ Akta soborowe nawiązują do dwóch różnych wizerunków Jezusa nie ręką ludzką uczynionych. Jeden z nich ocalił Edessę, obleganą dwukrotnie przez Persów w latach 542-544. Drugi natomiast był obnoszony wokół murów Konstantynopola w 626 r. i ocalił miasto przed atakiem perskim. Por. L. Brubaker, Inventing Byzantine Iconoclasm, London 2012, s. 11.

${ }_{65}$ CUNS, s. 580-584.

${ }^{66}$ CUNS, s. 426.

${ }^{67}$ CUNS, s. 156, 362, 614, 786.

68 CUNS, s. 358.

${ }^{69}$ CUNS, s. 380-382. 
cji zwycięstwa ${ }^{70}$. Rola ikony polega przede wszystkim „,na uwolnieniu od idolatrii i oszustwa demonów, a zwróceniu do światła, prawdy i miłości Boga"71.

\section{Podsumowanie}

Akta Soboru Nicejskiego II to najważniejsze źródło dla odkrycia miejsca i roli ikon w Kościele. Żaden inny sobór nie poświęcił tyle miejsca obrazom i w tak systematyczny i całościowy sposób nie potraktował tego zagadnienia. Wypracowana przez ojców soborowych - w odpowiedzi na zarzuty ikonoklastów - argumentacja za tworzeniem ikon i oddawaniem im czci stanowi rzeczywiste kompendium wiedzy nie tylko o samych ikonach, ale i o źródłach i sposobach uzasadnienia głoszonej przez Kościół doktryny.

\section{BIBLIOGRAFIA}

\section{Źródla drukowane:}

Concilium Universale Nicaenum Secundum. Concilii actiones I - III, edidit Erich Lamberz, Walter de Gruyter, Berolini - Novi Eboraci MMVIII.

Concilium Universale Nicaenum Secundum. Concilii actiones $I V-V$, edidit Erich Lamberz, Walter de Gruyter, Berlin-Boston 2012.

Concilium Universale Nicaenum Secundum. Concilii actiones VI-VII, edidit Erich Lamberz, Walter de Gruyter, Berlin-Boston 2016.

\section{Opracowania:}

Brubaker L., Inventing Byzantine Iconoclasm, London 2012.

Brubaker L., Haldon J., Byzantium in the Iconoclast Era, c. 680-850. A History, Cambridge 2015.

Congar Y., Tradycja i tradycje, Poznań-Warszawa 2018.

Ewagriusz Scholastyk, Historia Kościoła, tłum. S. Kazikowski, Warszawa 1990.

Giakalis A., Images of the Divine. The Theology of Icons at the Seventh Ecumenical Council, Leiden 1994.

Gilski M., Migdał M., Problematyka złego ducha w debatach Soboru Nicejskiego II, „Bielsko-Żywieckie Studia Teologiczne” 17 (2016), s. 111-118.

Gilski M., Cholewa M., Język soborów pierwszego tysiąclecia, Kraków 2018.

Łukaszuk T. D., Obraz święty - ikona w życiu, w wierze i w teologii Kościoła, Częstochowa 1993.

70 CUNS, s. 546.

71 M. Gilski, M. Migdał, Problematyka złego ducha $w$ debatach Soboru Nicejskiego II, „Bielsko-Żywieckie Studia Teologiczne” 17 (2016), s. 117. Por. CUNS, s. 126. 
Sahas D. J., Icon and Logos. Sources in Eight-Century Iconoclasm, Toronto-Buffalo-London 1986.

Schönborn Ch., Ikona Chrystusa, Poznań 2001.

Solovieva O., Epiphanius of Salamis and His Invention of Iconoclasm in the Fourth Century A.D., „Fides et Historia” 42 (2010), z. 1, s. 21-46.

Thümmel H. G., Die Konzilien zur Bilderfrage im 8. Und 9. Jahrhundert. Das 7. Ökumenische Konzil in Nikaia 787, Padeborn-München-Wien-Zürich 2005.

Tschiflianow B., The Iconoclastic Controversy - A Theological Perspective, „The Greek Ortodox Theological Review” 38 (1993), s. 231-264.

Uspienski L., Teologia ikony, Poznań 1983.

\section{Streszczenie}

Artykuł prezentuje argumentację za kultem ikon przedstawioną w czasie obrad Soboru Nicejskiego II. Argumenty mają charakter teologiczny, filozoficzny, socjologiczny i logiczny. Spośród jedenastu przytoczonych argumentów najwięcej miejsca w aktach soborowych zajmuje opis cudów dokonanych za pośrednictwem ikon.

Słowa klucze: ikona, argumentacja, Akta Soboru Nicejskiego II, Siódmy sobór ekumeniczny

\section{Arguments of the Second Council of Nicaea for the Cult of Icons}

\section{Summary}

This article presents the arguments for the cult of icons presented during the Second Council of Nicaea. The arguments are theological, philosophical, sociological and logical. Of the eleven arguments cited, the largest part of the conciliar acts regard the depiction of the miracles performed through icons.

Key words: icon, argumentation, The Acts of the Second Council of Nicaea, The Seventh Ecumenical Council 